RESIDENT

\& FELLOW

SECTION

Section Editor

Mitchell S.V. Elkind,

MD, MS

Max R. Lowden, MD

David Gill, MD

Address correspondence and reprint requests to Dr. Max R Lowden, Department of Neurology, The Pennsylvania State University Milton S. Hershey Medical Center, 30 Hope Drive, Hershey, PA 17033 Mlowden@hmc.psu.edu

\title{
Teaching NeuroImage: Idiopathic hypertrophic spinal pachymeningitis
}

\begin{tabular}{|ll}
\hline Figure 1 & $\begin{array}{l}\text { Sagittal and axial MRI T2-weighted } \\
\text { images }\end{array}$ \\
\hline
\end{tabular}
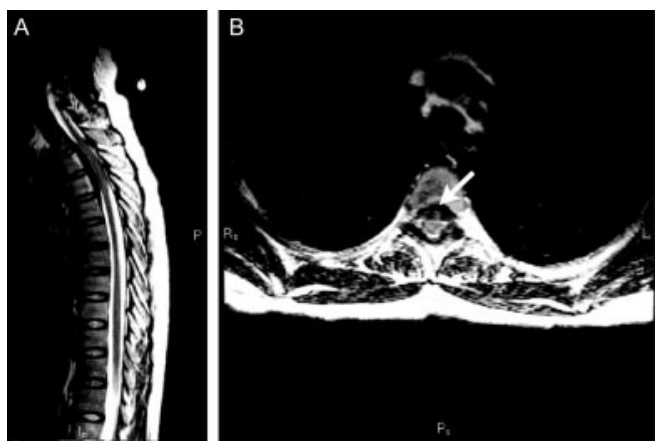

(A) Sagittal MRI T2-weighted image showing a dural lesion of low signal intensity within the spinal canal at levels T2 to T5 extending anteriorly. (B) Axial MRI T2-weighted image at T3 and T4 level showing a dural mass (white arrow) in the anterior aspect of the spinal canal.

A 42-year-old woman had progressive numbness from both feet to mid chest for 2 weeks. Examination showed a sensory level at T8, no weakness, and brisk reflexes throughout.

MRI showed T2-T5 dural thickening (figure 1). Testing revealed an elevated sedimentation rate and normal chest $\mathrm{x}$-ray, CSF analyses, and tests for rheumatologic diseases and infections. Dural biopsy showed an inflammatory infiltrate (figure 2).

Idiopathic hypertrophic pachymeningitis is a diagnosis of exclusion since it is associated with trauma, infection, and autoimmune diseases.

\begin{tabular}{|l} 
Figure $2 \quad \begin{array}{l}\text { Hematoxylin and eosin stain of dural } \\
\text { mass showing a chronic } \\
\text { inflammatory infiltrate consisting } \\
\text { of plasma cells and lymphocytes }\end{array}$
\end{tabular}

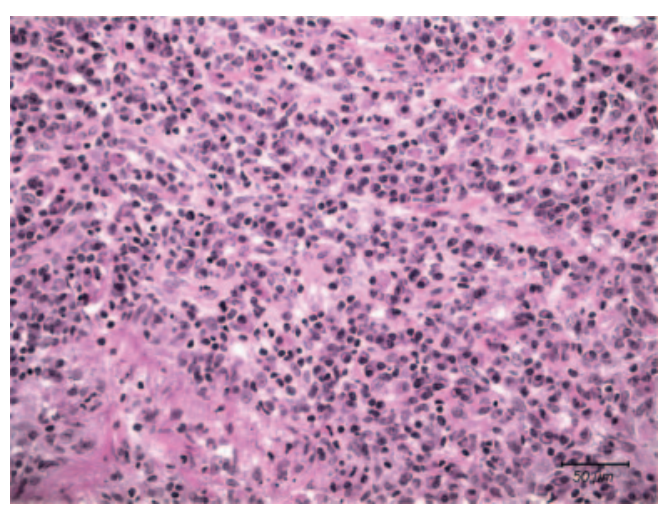

There is also fibrosis and reactive fibroblasts throughout.

Treatment consists of corticosteroids and steroid sparing agents. ${ }^{1}$ It is usually found intracranially and rarely involves cervical and higher thoracic levels. $^{2}$

\section{REFERENCES}

1. Kupersmith MJ, Martin V, Heller G, Shah A, Mitnick HS. Idiopathic hypertrophic pachymeningitis. Neurology 2004;62:686-694.

2. Pai S, Welsh CT, Patel S, Rumboldt Z. Idiopathic hypertrophic spinal pachymeningitis: report of two cases with typical MR imaging findings. Am J Neuroradiol 2007;28: 590-592.

From the Department of Neurology, The Pennsylvania State University Milton S. Hershey Medical Center College of Medicine.

Disclosure: The authors report no disclosures. 


\section{Neurology}

\section{Teaching NeuroImage: Idiopathic hypertrophic spinal pachymeningitis \\ Max R. Lowden and David Gill \\ Neurology 2009;72; 27 \\ DOI 10.1212/01.wnl.0000341880.99861.1e}

This information is current as of February 2, 2009

\section{Updated Information \& Services}

References

Subspecialty Collections

Permissions \& Licensing

Reprints including high resolution figures, can be found at: http://n.neurology.org/content/72/5/e27.full

This article cites 2 articles, 1 of which you can access for free at: http://n.neurology.org/content/72/5/e27.full\#ref-list-1

This article, along with others on similar topics, appears in the following collection(s):

All Spinal Cord

http://n.neurology.org/cgi/collection/all_spinal_cord Meningitis

http://n.neurology.org/cgi/collection/meningitis

Information about reproducing this article in parts (figures,tables) or in its entirety can be found online at:

http://www.neurology.org/about/about_the_journal\#permissions

Information about ordering reprints can be found online:

http://n.neurology.org/subscribers/advertise

Neurology ${ }^{\circledR}$ is the official journal of the American Academy of Neurology. Published continuously since 1951, it is now a weekly with 48 issues per year. Copyright. All rights reserved. Print ISSN: 0028-3878. Online ISSN: 1526-632X.

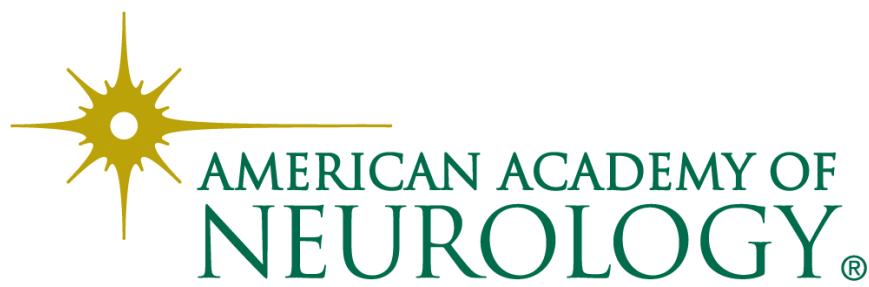

